\title{
BIM in the Water Industry: Addressing Challenges to improve the project delivery process
}

\begin{abstract}
Purpose

The UK water industry is a private sector that has no government mandate to implement BIM but would benefit from its use. Research has identified that fragmentation and inefficiency still existed in the water industry project delivery processes. These issues can be addressed by harnessing the collaboration that Building Information Modelling (BIM) brings by using emerging information technology. The UK water industry has had little research in the use of $\mathrm{BIM}$ in the project delivery processes over the years.
\end{abstract}

\section{Design/methodology/approach}

The aim of the research is to explore and examine BIM elements currently used in the water industry, as well as understand the organisational cultural support for BIM. It also investigated the adoption of BIM which will enable to improve water industry project delivery processes. An empirical study was performed in the UK. Given the relatively new and unexplored nature of the research problem, a qualitative research methodology was adopted. In total, 14 semi-structured interviews from six water sector organisations were conducted to collect data, which was then analysed using thematic analysis for inference and conclusion.

\section{Findings}

The study identified that BIM has already changed how projects are delivered by the water companies and their supply chain. Use of emerging technology such as Autodesk Revit, Civil $3 \mathrm{D}$, and virtual reality has gained traction and is leading organisations to continue investing in these areas to remain relevant. Although staff training was offered by all organisations within the study cohort, some interviewees still thought that more can be done by their organisations as BIM is still maturing. Those interviewed regarded BIM models as data and information rich with the ability to enable the supply chain to obtain quicker approvals.

\section{Originality/value}

The paper provides a richer insight into the understanding and awareness of BIM elements used in the water industry to improve project delivery processes. This study shows that the water industry supply chain has taken positive steps and started to benefit from BIM use. It also recommends that there is a need for cross-sector collaboration to capture and share best and worst practices relating to BIM adoption in the water sector. 


\section{Introduction}

The UK water industry has been undergoing significant changes which have impacted on water companies and its supply chain. Between the 1930's and 1960's, the water industry vastly grew as the growing population demanded the drive for the increase in productivity. Each area in the UK organised water supply and wastewater services where the decision was made by an individual Act of Parliament or Royal Charter led to the different parts of the UK having different levels of water quality. During 1959 and 1960, there was severe flooding and drought which led the Water Resources Act in 1963 to implement some changes (McKibbin, 2014). This Act in 1963 focused on the approach to water resources and planning, introducing a co-ordinated approach to allow the removal of groundwater ultimately preserving the existing and potential water resources (Ofwat, 2019).

Between the years of 1965 to 1989, the water industry received huge investments in grants to enable the proper maintenance of the existing assets and construction of new assets to accommodate for the growing population (Akintoye and Renukappa, 2013). This action however needed a better management of water resources. In 1973, The Water Act stated how it required regional water authorities, where 10 were then established. The authorities took responsibility of managing the water resources and supply in an integrated manner (DEFRA, 2019). Since this action took place, it was found that there was a $99 \%$ reduction of consumers all around the UK experiencing low water pressure since 1990, less water leakages were experiences and revenue also doubled up (Akintoye and Renukappa, 2013).

Since the water industry's privatisation was 25 years ago, over $£ 100$ billion has been spent (NCE, 2014). The National Audit Office (NAO, 2015) expects a capital expenditure of $£ 44$ billion in Asset Management Period (AMP) 6 (2015-2020) whereas Hackett (2018) predicts an expenditure of $£ 50$ billion in the next AMP7 (2020 to 2025) which is a 13\% uplift from AMP6. However, there have been calls for infrastructure investments to be based on sustainable and efficient solutions to meet an increase in population, climate change and technological changes. Most of the existing water infrastructure is the creation of engineering innovations from Victorian times. Although this is an incredible legacy, it has not been nurtured as it should be particularly over the last forty years. Until recently, capital investment programmes have been undertaken to varying degrees by the water companies to upgrade its infrastructure (CST, 2009).

The main focus for the water industry is to provide safe drinking water and effective sewage water treatment facilities to its growing population. The water industry in the UK consists of small Water Only Companies (WOC) and Water and Sewage Companies (WaSCs) (Ofwat, 2019). The WaSCs are larger than the WOC's and apart from serving the growing population, large infrastructure projects are on the go as the UK government has invested billions of pounds into infrastructure within the next few years (HM Treasury and Cabinet Office, 2016), where the water sector is to facilitate this investment by producing water supply and sewerage services to accompany the infrastructure growth. 
Ofwat, (The Water Services Regulation Authority) conduct price reviews yearly with all UK water companies detailing how the companies proposed to deliver customer satisfaction (Potton and Adcock, 2019). Within the latest Price Review (PR19 - Price Review 2019) Ofwat are set to challenge the water companies in the UK to improve the flexibility of the services that they provide, this includes long term planning for their assets to account for the population growth and climate change. There are three main challenges the water industry faces today which are as follows (Bevan, 2019; Potton and Adcock, 2019):

- The Operational Challenge: the operational challenges can be simply outlined as enabling things to be done better within the sector, improving the value of money and having a quick response to the unexpected which are most of the challenges all public sector organisations face.

- The Climate Challenge: as referred to as the Jaws of Death (Bevan, 2019, in around 20 years from now, the predicted water demand and water supply will require water companies to increase their water supply drastically to supply our needs. As the summers become hotter and drier in the UK, there is a risk to more water shortages and extreme droughts.

- The Political Challenge: Major parties within the UK political scene are aiming to rationalise the water industry, however a set plan on obtaining this is not available, this could mean that the water industry could lose support as a whole country.

Rezgui and Zarli (2006) highlighted that the construction industry is moving from using traditional physical elements to information technology software with intelligence. This was supported by Hardin and McCool (2015) who pointed out that the construction industry was in the midst of a technology renaissance; however, the new technology did not fit into the previous project delivery processes. The NCE (2014) further ruled the processes as inefficient needing more collaboration and integration. These processes were also deemed broken in 2017 leading to delivering expensive assets, poor performance and failed to make best use of emerging technology (ICE, 2017). However, Owen, et al, (2010) noted that the use of collaborative Building Information Modelling (BIM) presents opportunities to remove these inefficiencies. Using BIM involves sharing of information and presents diversity of risk areas hence there is a need to identify challenges and barriers which becomes a prerequisite to its application (Khosrowshahi and Arayici 2012).

Moshtaghian et al., (2020) noted that within the framework of building information modelling, merging and updating project information along with recording changes can provide dynamic risk identification at all stages of the project. This was done using 5D model by creating an integrated risk identification platform to reduce rework, change management, time and cost control leading to improved risk-taking efficiency of the project. Saieg et al., (2018) systematically explored the combination of sustainability, lean and BIM studies and developed an interrelationship matrix which provides significant opportunities to reduce economic and environmental impacts. It suggests that the integration mechanism is effective in decision making during conceptual design and construction stages of the project. 
BIM4Water (2017) report highlights the key BIM implementation guides such as a wider overview of PAS1192 (British standard for the management of information) within the water industry which includes the organisations information and asset information requirements. Big organisations tend to undertake most capital work due to stronger financial positions and likely face more difficulty in the use of BIM (Miller, 2012). However, financial implications and skills shortages on BIM implementation were cited by Sinclair (2012) as barriers. Azhar et al, (2008) identified model ownership as the first barrier for BIM use. These challenges might become hindrances to project progression if not addressed.

The UK Government has stated a key aspiration for the construction industry to be efficient and technologically advanced through the Construction Strategy 2025 (HM Government, 2013). There is emphasis on the use of BIM being able to form a basis for meeting efficiency and technological 2025 targets. These targets include achieving 33\% cost efficiency, delivering 50\% faster and achieve 50\% reduction in greenhouse gases emissions. However, there is a realization that there is a great challenge to fully embrace and implement BIM (HM Government, 2013). This provides a significant driver for this research paper for water industry projects.

The NCE (2014) stated that there is a need to think differently. Water companies and its supply chains must be more integrated and collaborative. Inherently, most water companies are set up around planning, delivery and operations as different departments with a breakage somewhere between the two components. BIM would solve the above stated issues if BIM is used correctly (Kemp, 2014). Furthermore, significant efficiencies, cost savings and improved delivery of client's value in construction can be achieved by correctly utilising BIM (ICE, 2015). It was expected that BIM will advance its importance in the UK water sector AMP6 period.

$\mathrm{Bu}$ et el., (2015) explored the current technology developments that support green retrofit design and provides decision support models for architects to become involved in reducing carbon emissions in pre-design stages based on review of literature. This work compared designing green new build projects with the green retrofit design process with sustainable design aspects for commercial buildings. BIM is increasingly popular for Integrated Project Delivery for early collaboration and effective decision making in the building industry.

Bensalah, et al., (2019) explored the positive impacts of integration of BIM with the railway infrastructure projects, through a theoretical and practical study. The benefits of integrating BIM into rail projects include: cost control, decision support, avoids extra work due to design errors, improves detection of interface problems, improves planning of vision, help with prefabrication and facility management. However, authors noted that the integration of BIM requires government decisions and a maturation of technology and tools.

Rezgui et al, (2009) stated that despite the advantages that follow BIM utilisation, there are 
several issues that have derailed its adoption. The concerns include trust, authentication, security, validation, quality, ownership and other related issues. By addressing these concerns and challenges construction projects would yield the benefits associated with effective BIM use. In addition, UK water projects will meet the objectives set by Ofwat and address the shortfalls identified by Latham (1994) and Egan (1998).

\section{Research Gap}

The UK Government mandate for the use of BIM for all public projects starting from 2016 formed the major driver for the construction industry to upskill and learn new ways of working. BIM guidance for the water industry summarises the benefits that can be obtained from the use of BIM within the industry which highlights service, customer and operation benefits for the water industry (BIM4Water, 2017). However, the water industry was not mandated to use BIM for project delivery as it a private sector. This is despite having very technically complex projects with assets that are to be maintained which could benefit from BIM implementation and can have a positive impact within the sector. Within the water sector, a typical asset such as a water treatment plant or a pumping station will require vast number of skills from different industry specialists.

There has been very little research in the use of BIM to address key challenges faced in the water industry that have been raised over the years. BIM has been around for over a decade and while most industries have embraced digital BIM with the latest technological opportunities, some sectors, including the water industry are still facing major challenges in regard to implementing a fully digital strategy. Engineers within the industry tend to think $\mathrm{BIM}$ as having access to a 3D platform that enables a more collaborative approach to the creation of an asset and also provides better information management (Wei, et al., 2017). BIM encourages an efficient design of assets by changing the traditional way of designing the assets, constructing them and managing them post-construction (Liu, et al., 2019).

Between the years of 2011 and 2019, the NBS (2019) annual report shows a significant growth in respondents that are aware and using BIM within their projects. The figures rose from $13 \%$ to $69 \%$. At the moment in the UK, BIM is being utilised for better collaboration, communication and evaluation to facilitate management objectives all throughout the stages of construction and through asset management (Liu, et al., 2019). In itself, helps address one of the key challenges that have been highlighted by Egan (1998). Thus by addressing current challenges in implementing BIM will improve the water project delivery process. Hence the aim of the study is to explore and examine the implementation of BIM in the water industry, challenges faced and how to address them can improve the project delivery processes.

In doing so, methodologies and processes that are followed in water project inception through construction to handover, forms the first section of this paper. The second section forms the research methodology as a qualitative research approach was undertaken for the study. The research findings follow which are categorised based on recurring themes of organisational 
support for BIM, elements in use, adoption and next steps. The final section is on the research conclusions and recommendations.

\section{The water project delivery process}

The UK water industry's key purpose is to provide safe drinking water and effective wastewater management (CIWEM, 2010). As stated before, it consists of relatively small Water Only Companies (WOCs), and Water and Sewerage Companies (WaSCs), which are larger and offer water supply and sewerage services (see Table1). These can be regional or local companies, (a) water supply and (b) water supply and sewerage licensees and infrastructure providers delivering large infrastructure projects. Most customers are served by monopoly water companies for their water and sewerage services (Ofwat, 2019).

Please insert Table 1 here

The UK water industry operates on five-year cycles, called Asset Management Planning periods (AMP) where projects are planned, and budgets set. Under the regulation of Ofwat, (The Water Services Regulation Authority) water companies submit price reviews (PR) to Ofwat which detail their proposals on how they intend to deliver customer needs and wants, the latest being PR19, i.e. Price Review 2019. Ofwat reviews them and provides water companies with feedback on approval, rejection, requirement for more information or revision of proposals (Ofwat, 2019).

Bailey (2003) stated that the water industry's significant capital works is carried out and provided by the construction industry engineering and construction organizations. These organizations form the supply chain which has technical expertise that allows them to undertake capital works as delivery partners to the private water companies. To date, creation of frameworks, with fewer partners in a settled supply chain have been undertaken in response to the publication of the Egan and Latham reports which highlighted the need for greater collaboration between clients and the supply chain (Cabinet Office, 2011). Anglian Water named its framework partners for the current and future AMP in 2014 with contracts that span 15 years (Anglian Water, 2014). Back in 2013, Thames Water's Asset Director Lawrence Gosden, stated that "the decision to deliver the investment programme using an alliance marked a complete transformation in the way the company delivers capital investments" (Thames Water, 2013). United Utilities, Wessex Water, Severn Trent Water, Southern Water, Yorkshire Water and Welsh Water are other companies that have also created frameworks (Construction Enquirer, 2015).

Most UK construction projects are delivered following the model developed by the Royal Institute of British Architects (RIBA) called the Plan of Work. The Plan of Work is a process model for delivering building and construction projects which provides a shared framework for organization and management. It is widely used as a process map and a management tool providing work stage reference points, in a multitude of contractual, appointment documents and best practice guidance (RIBA, 2012). 
Stage 0 is developing of strategies which define project descriptions (RIBA, 2012). Water companies' Project Reviews submission to Ofwat form Stage 0 for some projects, which are prepared carried out their internal teams (Ofwat, 2015). The project is strategically appraised and defined before preparing a detailed project brief. The strategic definition stage which is also called the inception stage, is where the decision to invest in a construction or development project is made (CIOB, 2010).

During Stages 0 and 1, the Project Brief is developed which is a description of the project scope. Stage 2 is for Concept Design development and includes preparing outline designs, specifications, proposals, strategies and cost data whereas Stages 3 and 4 are for design development which lead into construction i.e. Stage 5 . The next stages 6 , and 7 are handover, and operation and maintenance respectively (RIBA, 2012 and Anglian Water, 2014).

\section{BIM in the Water industry project delivery process}

Within the digital world, BIM can be defined as "a world of interactive cloud-based models, virtual reality headsets, immersive design projections you can walk through and lasers that can scan, map and recreate a building or a piece of equipment" (Smith, 2016). Similarly, the Construction Project Information Committee (CPIC, 2015) defines BIM as "digital representation of physical and functional characteristics of a facility creating a shared knowledge resource for information about it forming a reliable basis for decisions during its life cycle, from earliest conception to demolition”. BIM itself is not a technology but a data rich model-centric business process with the power to transform project delivery. This transformation adds value across the full lifecycle of infrastructure assets - plan, design, build and manage. It is a knowledge process about the way to build things (Autodesk, 2015a) and involves creating and utilizing intelligent 3D models (Autodesk 2015b). For the purposes of this paper, the BIM definition by CPIC (2015) will be adopted.

The UK Government BIM Task Group established the BIM4Water Group after publication of the Construction Strategy (BIM4Water, 2015). This is a cross industry group open for all organizations involved in the delivery and management of water and wastewater projects in order to support adoption of BIM. The BIM4Water (2017) Task Group highlighted that BIM is already changing how capital projects are being delivered and how asset information is created and exchanged; this has been delivered benefits and created value opportunities throughout the asset management cycle. These opportunities are driven by use of digital technologies in capital projects. Howell et al (2017) work applies ICT and artificial intelligence to water management and has proposed a detailed ontology, and a semantic web service, which integrates GIS and topological network descriptions, telemetry data, BIM, smart metering, and smart appliances. The findings suggest that semantic web and Internet of Things technologies can merge to bring together large models, such as in BIM, with dynamic data streams, to support powerful applications in the operational phase of built environment systems. Rahimian et al (2020) developed a framework and proof of concept prototype of a hybrid system by integrating image processing, machine learning, BIM and Virtual Reality concepts. Construction companies could use the developed prototype as a remote managing 
tool to save time and provide a more accurate comparison of constructed parts with the asplanned BIM model.

BIM4Water (2017) regarded BIM as a business change that will take years to fully embed requiring investment in processes, people and systems to yield long term benefits. There is a need to align BIM with data, information, digital strategies and security across the water industry. This will lead to BIM evolving to become more aligned with national BIM standards to deliver aspirations set out in the UK Government Construction 2025 Strategy. BIM4Water (2017) has called the water industry players to be part of the Digital Britain to enable accessing new efficient ways of working as in the case studies below.

The Anglian Water Recycling Centre Extension project was carried out using BIM which showed significant improvements in business processes yielding delivery time and cost savings. The Semer Water Treatment Works, an Anglian Water project used 3D modelling aligned with programme and the associated commissioning plan which led to removal of significant business risk associated with an old unreliable borehole source. Severn Trent Water use of BIM on the Minworth wastewater treatment facility project led to a $£ 5$ million and 13.5\% cost saving (BIM4Water, 2019). According to NCE (2014), BIM real benefits go to the client as it can reduce whole life costs of the asset during operations. There is the recognition by clients, contractors and consultants that the significant benefits of BIM use stem from sharing of data throughout the project lifecycle, optimising design performance, reducing errors and reduced project durations. BIM offers a unique opportunity and is regarded as the driver to revolutionize construction projects delivery. This is a shift from the traditional inefficient paper-based processes with fragmented project teams to a more integrated, seamless transfer of data between collaborators who are incentivized to deliver whole life cost savings (Building, 2014).

Implementing BIM has not been without its challenges as it is a new way of working. Khosrowshahi and Arayici (2012) and RIBA (2012) stated that the main challenges to the use of BIM has been firms not being familiar to its use, unwillingness to train staff, or initiate culture changes or new processes or workflows, unwilling to procure respective software and technology. BIM4Water (2015) goes on further to state there is a need raise BIM awareness through training people on how to manage and using asset data. Other challenges and barriers to BIM adoption include (a) higher expectations from the supply chain, (b) inconsistent or multiple protocols, (c) significant culture change to adopt BIM, (d) lack of informed clients and (e) the need to define new roles. It is apparent that challenges stem from the need to change from business as usual organizational cultures which comes with progression into the unknown BIM environment (BIM4Water, 2017). According to BIM4Water (2017) BIM has not fully matured in the water industry despite making some progress and there are no empirical study in the subject. Hence there is a need to explore and examine how UK water companies are implementing BIM within project delivery setting, to understand the challenges and thus identify solutions to solve them. This would enable water projects achieve the cost and programme benefits of using BIM. 


\section{Research Methodology}

According to Schwandt (2001) methodology is defined as a theory of how enquiry should progress. Schwandt (2001) goes on further highlighting that it involves analysis of assumptions, principles and procedures in a certain approach to inquiry. Project delivery is steered by an overall project manager (CIOB, 2010) who will be suitable to provide a thorough insight. There is limited material written on adoption of BIM onto water projects and thus there is a need to fully ascertain how this is understood, considered and experienced in this industry. This leads to a requirement to observe and experience processes relating to project delivery and BIM requiring qualitative data (Holt, 1998). A research should be conducted to correspond with the availability of needed data (Neuman, 2014). The data in question was perceptions on experiences on BIM elements in current use, organizational culture support for BIM and BIM adoption and next steps on water projects delivery processes. Hence a qualitative research approach was chosen as the most suitable method for this research. A qualitative research is undertaken in order to understand the context or settings in which participants address a problem or an issue (Creswell and Creswell, 2018). Naoum (2007) goes on further stating that it's subjective in nature and emphasises on meanings, experiences and descriptions. According to Holt (1998) it also involves personal opinions, perceptions or feelings. Farrell (2011) highlights qualitative research as being a pattern which seeks to find relationships between different categories. Denzin and Lincoln (1998) summarise qualitative research as a field of inquiry in its own right. This corresponds with the research topic which requires understanding of the perceptions and experiences of the water industry processes. In turn, understanding how adoption of BIM within the water sector is seen as the enabler to improving project delivery processes.

Creswell and Creswell (2018) stipulates that qualitative research involves collecting data in the natural setting by talking directly to people and seeing their behaviour and actions. Hence great emphasis should be on getting the needed data, its purpose, questions to ask and how it is extracted (Robson, 2011). Primary data for the research was obtained directly from interviewees in the water industry. The research sample included water framework partners, which included the water company (the client) and engineering consultants (designer and contractors). This creates a unique sample which encompasses a common approach, allowing obtaining of lessons learnt, sharing of data and due care in sample selection (Naoum, 2007). The selection of the consultants and Water Company presented a good representation of the UK countrywide water sector. This is because both are in frameworks across different water companies, whilst implementing BIM. This presented greater validity and trustworthiness on the findings (Hart, 2005). Respective verbal communication followed by written contact was made to ensure that the research was formal reassuring the organisations of ethical research, confidentiality and anonymity. The researcher was given exclusive access to obtain secondary data from internal data storage drives and use of the intranet, an online portal.

Creswell and Creswell (2018) identifies four data collection methods in qualitative strategies namely observations, interviews, documents and audio-visual materials. All these data collection methods were used, except audio-visual methods, in this research in order to 
establish a "rich" collection of information determining strong relationships. This approach is supported by Corbin and Strauss (2008). The research observations were carried out on the project delivery teams between office and construction sites. The project delivery teams consisted of project managers, design engineers, CAD and BIM Technicians, client representatives, and other stakeholders. The observations were carried out on participants' behaviours and how they delivered projects on a day to day basis (see Table 2 for sample observation protocol). This included the team interactions, meetings, discussions, communications, and day to day activities of carrying out project work. The project work included stakeholder engagement, third parties involvement, design activities, documentation, drawings, and site meetings.

\section{Please insert Table 2 here}

The researcher's rapport with the participating organisation enabled unlimited access to all relevant research documents. However, strict confidentiality had to be observed on some documents and images which were deemed to be commercially sensitive. Though these may not be included in this paper, reporting of findings has been made relevant to the research. This enabled to verify the behaviours of the participants during the observation period.

A total of 15 water utilities organisations in UK were contacted of which six organisations agreed to participate in this study. Firstly, the organisations were sent the invitation letter which stated about the research, ethical aspects of conducting interviews and the benefits of participating (i.e. sharing the summary of the results). Within the six organisations, the sample included design lead, project leader/managers, technical manager, programme engineer/manager, asset manager/operator, BIM team leader, BIM technicians and CAD technicians as presented in Table 3. Formal face-to-face interviews were set to a time limit of at most an hour to avoid disruption of work activities. It was felt like this was more than adequate to obtain the required and rich data. The participants were notified of the confidentiality of their responses to ensure that they were free and open on their responses (Neuman, 2006).

\section{Please insert Table 3 here}

An important sample size issue in qualitative research involves saturation of information (Strauss and Corbin, 1998). The sample size of this study was based on the principles for data saturation theory explained by Francis et al. (2010). Saturation is a term used to describe the point when no new insights or range of ideas are generated through adding more data. In this study, data were collected until no new aspects of the BIM strategies were revealed. In this study, actual saturation of data occurred before the 12 interview. Therefore, to ensure greater dependability and transferability (Creswell and Creswell, 2018), a total of 14 professionals from six UK water utilities organisations were interviewed. The format of these interviews was face-to-face, and the transcripts were recorded and supplemented with field notes as 
appropriate. To assist with the data analysis, a 5-step process based on Creswell and Creswell (2018) guide for qualitative data analysis was utilised. Overall these steps are transcription of audio interviews; preparation of transcripts; iterative review of transcripts; coding of transcripts; generations of themes.

In the study, coding of the transcribed documents involved open coding of meaning units, that is, words, phrases, sentences, paragraphs, which essentially involved labelling concepts. The emerging concepts were mapped into themes. The themes have been cross-checked on group discussions between the authors and two fellow researchers. Threats to validity were minimised through triangulation of data collection methods (interviews, observations, internal and external documents) and verification of the initial thematic codes by participants, where they judged the accuracy of data collected, though not its conclusions (Tajeddini and Mueller, 2009).

\section{Findings}

The research findings are presented below under three themes namely (a) BIM organizational culture support (b) BIM elements in current use (c) BIM adoption and next steps.

The three regional water companies deliver numerous projects under the Asset Management Periods (AMP) with the three engineering consultancies and associated construction delivery partners carrying out the majority of this work. These organisations thus provide useful BIM application references that can be used following an inter-organisational approach.

\section{BIM organizational culture support}

All the organisations use online, live collaborative working platforms which can host vast amounts of information. Autodesk (2015a) pointed out that the use of cloud-based technology in BIM allows carrying out multiple iterations of very complex analyses in near real time versus minutes, hours, or days. BIM is regarded as a shift from the traditional way of delivering projects and requires organizational culture process acceptance and changes to implement it. According to Aranda-Mena et al, (2009), BIM facilitates integration of fragmented practices and acts as a catalyst for changing business processes.

Construction projects have always faced the challenge of being known to be delivered inefficiently, with cost and programme overruns, lack of integration and poor risk management (Egan, 1998). The study identified that BIM has already changed how projects are delivered by the six organisations, water companies and their supply chain. The organisations set up IT systems that allow hosting collaborative BIM technology and processes. For organizations A, D and E, they all rolled out an industry collaborative working platform, called ProjectWise, a collaborative project delivery cloud-based platform which owned and hosted by Bentley. The organisations continued to train their staff in the use of 
ProjectWise and associated packages. However, the study has identified that organisations A, $\mathrm{D}$ and $\mathrm{E}$ use BIM software, processes and collaborative platforms; organisations B, C and F only used collaborative platforms with no capability or resources assigned to developing BIM expert level of information. These organisations, as utility companies provided financial support to progression of capital projects as the clients. The practice observed is that there is no need for the client to have BIM modelling software capabilities, but rather that of hosting and commenting on that developed by the engineering consultancies. A project leader interviewed highlighted that using BIM by client organisations was being considered, and used based on their role, as the intention is to provide the information to the right person at the right time.

"Our particular client has not yet developed much understanding of BIM. The first area they are looking at is improving records management in the operational phase, rather than new asset delivery.” (Organisation A - CAD technician)

At project inception and during reviews in organisations A, D and E, the senior management, took the initiative in prompting project managers to consider using BIM, or its elements for project delivery. Organisations A, D and E managed to draft and implement BIM Execution Plans (BEP) as key reference and strategy documents for the respective framework contracts with water companies, making it a reference document for project delivery. A project leader in organisation A supported its use stating "this has provided us with a clear path for our BIM strategy, identified required staff training, software and hardware requirements and expected deliverables". The BEP for organisation A also listed the IT systems that needed to be used to support BIM. Organisation A put in place measures to support BIM, as they had identified this as an enabler for realising BIM benefits. A project manager in organisation B highlighted that their BIM use and level of expertise for water projects was still in its infancy as the BEP has been in draft format, with no updates for more than a year. This shows that BIM way of working has not been prioritised by organisation $\mathrm{B}$, and that the raising awareness challenge raised by BIM4Water (2015) existed in this organisation, contrary to organisation $\mathrm{A}$. This is despite organisation $\mathrm{B}$ having addressed the challenge of procuring respective BIM software.

RIBA (2012) points out that there is a need to address the staff training challenge for utilising BIM and that upcoming designers and contractors should embrace the new collaborative working methods. During one of the interviews with a CAD technician from organisation D, it was apparent that more still needed to be done as there were limited budgets. In addition, the existence of other urgent work, and lack of CAD resources meant that there was limited time to undertake training. The interviewee expressed a willingness to use BIM software for developing design models that felt like not enough support was afforded to them. One of the key CAD technicians in organisation $\mathrm{D}$ trained themselves in the use of BIM software, creating information templates for BIM implementation, which in turn has benefitted their organisation. Although, staff training was offered by all the organisations within the study cohort, some interviewed still thought that more can be done by their organisations as BIM is still maturing. However, in organisation A, BIM technicians were allocated training budget 
associated with their skill level and regular training was encouraged by management to ensure that experience was passed onto their respective projects. Observations made pointed to allocation of external and internal for a day a week on BIM training with application of gained knowledge on live projects.

The Table 4 below summarises the BIM way of working measures in use across the organisations studied. It indicates that organisations $\mathrm{A}, \mathrm{D}$ and $\mathrm{E}$, the engineering consultancies have embraced, though not fully, BIM way of working. BIM4Water (2015) highlighted that the construction industry broadly agrees with BIM intended benefits but challenges existed which are associated with measuring the benefits, costs consistently and identifying recipients of the benefits and justifications. The utilities companies' interests lay in problem identification, and the need to implement solutions that enabled meeting regulatory requirements at the cheapest cost. The study observed that this was the approach for the research cohort as the water companies left BIM way of working to the supply chain as they saw them best suited to use it. It should be noted that the water companies carried out relatively very small asset maintenance projects which according to them did not justify investing in BIM processes.

Please insert Table 4 here

\section{BIM elements in use}

Bernstein and Pittman (2004) cited barriers to broader adoption of BIM as extending beyond the often-stated relationships between software applications to interoperability. The use of Industry Foundation Classes (IFC) is identified by the UK construction industry, through the National Building Specification as the solution to interoperability issues, as it allows exchanging relevant data between different software and is regarded as fundamental to open BIM (NBS, 2017). The NBS, do state the following;

“To achieve BIM's full potential the industry requires a robust mechanism to exchange the ever increasing levels of digital data, regardless of what software package or BIM platform is used.” (NBS, 2017)

In order to address the challenge of interoperability, the organisations, like the construction sector has been using Autodesk suite of software for implementing BIM way of working. The engineering consultancies, A, D and E were all found to be using Autodesk software suite which included Revit, Civil 3D, Navisworks, Design Manager, with organisation A also found to be using Piping \& Instrumentation Diagrams, and Revit to Excel links. Organisation D was found to be also using a software called Revizto, which is a three dimensional drafting software which allows designers and team members to leave comments in the project model. This enabled teams to develop outputs such as in Figure 1, which shows 3D models on the left used for team discussions, seeking approvals, design reviews and the schedules on the right used for procurement of various equipment and elements for site installation. None of 
the organisations used IFC, although a project leader in organisation $A$, and a CAD technician in organisation D knowing of its existence.

\section{Please insert Figure 1 here}

A programme engineer in organisation $\mathrm{B}$, a water utility company undertook an in-house presentation on a BIM delivered project stating "the generated and shared 3D models enabled site operatives to see the asset they were getting, which enabled them to recommend their preferences on access to plant and equipment for operations and maintenance activities.” In order to address the interoperability issue and lack of relevant software and use capability, the engineering consultancy, had to create pdf (free software) copy version of the 3D model for the programme engineer to share with his team. An in house presentation, using a laptop with installed Autodesk software was carried out by a CAD technician in organisation D to go through the project model with stakeholders. Observations made indicated that addressing this interoperability challenge with clients was carried out to gain quicker stakeholder approvals, saving programme time and cost.

Similarly, GCA (2015) implemented BIM by using the Autodesk suite tools, quite common in engineering design, which allowed saving hundreds of design hours, avoiding problems, saving project time, cost and identifying engineering opportunities in design. Azhar et al (2008) and BIM4Water (2017) highlighted that BIM can be used for purposes which primarily include three dimensional visualisations which are created directly from the models and contain underlying information. Those interviewed regarded BIM models as data and information rich with the ability to enable the supply chain to obtain quicker approvals from water company client managers and site operatives. Three dimensional models were shared and presented real-life representation of the asset to be built.

Review of the organisations intranets, observations and BIM4Water web pages indicated that they were all part of the BIM4Water Task group which aims to enhance the water industry BIM capabilities and develop standards. However, at project team level, this is not communicated by respective managers, the engineers' and technicians' with BIM interest came across it themselves through research. This finding supports a CAD technician from organisation D who highlighted that more needs to be done in their organisation.

A summary of the in-house measures implemented by the organisations are shown in Table 5. One of the other key benefits for the procurement teams is the ability to quickly obtain schedules exported into Microsoft excel for procurement and project capital cost build up as indicated by a project leader in organisation A. The measures have enabled to address the challenge of justifying the benefits of BIM use, in part, bringing the gap of lack of collaboration. The study found that there was general excitement in sharing processed 3D information, i.e. 3D models of the asset, and the capabilities of getting relevant, right information at the first time. There is the coming of age of the ability to extract data and information quicker than before BIM use which is having positive impact on project delivery programme, cost, and quality. 


\section{Please insert Table 5 here}

\section{BIM adoption and next steps}

BIM4Water and British Water have enabled meetings of the BIM4Water owner operator group formed in 2016. This group is made up of Water and Sewerage Companies in England, Scotland and Northern Ireland (BIM4Water, 2017). The water industry has been holding several workshops, seminars and events on BIM in the industry. The topics developed were being driven by the ever-increasing use of BIM in the water industry and how to reduce costs for asset owners, suppliers and contractors. It is highlighted that the water sector is beginning to reap the rewards of using BIM with an expectation that it will increase in the coming years (WIF, 2015).

The organisations in this study form part of the BIM4Water Group and continue to support its goal of supporting the water industry to implement BIM and realize the benefits. BIM is considered to be in its infancy regardless of the few years that have passed. Use of emerging technology such as Autodesk Revit, Civil 3D, Revizto, and virtual reality has gained importance and is leading organizations continue to invest in these areas to remain relevant. This was identified for all the organizations in this research. The following Table 6 summarises the study findings on how BIM is currently and is likely to be used in the future.

Please insert Table 6 here

\section{Conclusions and recommendations}

The UK government call for the construction industry to be at the forefront of technology has pushed the water sector to implement relevant systems, processes and tools. The water sector is referencing industry guidance through the BIM4Water Task Group, the Construction Strategy 2025 and Digital Britain. Hence the water industry has been investing more in emerging technology, especially BIM to address challenges brought by adherence to regulatory requirements and effects of unpredictable weather patterns and climate change. This however has come with in its own challenges of moving from business as usual for project delivery which the water companies are addressing through further investments. There has been very little research in the use of BIM to address some of the key challenges faced in the water industry that have been raised over the years. Therefore, aim of this research was to explore and examine BIM elements currently used in the water industry, as well as understand the organizational cultural support for BIM. It also investigated the adoption of BIM which will enable to improve water industry project delivery processes.

The study identified that BIM has already changed how projects are delivered by the water companies and their supply chain. The UK water industry has been lacking behind in 
implementing BIM as it is not mandatory. However, BIM has been adopted since other industries have been achieving positive benefits. These include achieving cost efficiencies, shorter project durations, and better-quality outputs. The water industry supply chain has started investing in procuring respective BIM software to allow them to implement it. Use of emerging technology e.g. Autodesk Revit, Civil 3D, and virtual reality has gained traction and is leading organizations continue to invest in these areas to remain relevant. The organizations have also put in place processes and cultures to ensure that BIM use steadily increases. However, there are challenges that continue to be faced which include lack of adequate training in some organizations due to budget constraints whereas others are doing well. The key benefits for the water industry on BIM implementation include visualizations in three dimensions of the assets to be built to obtain client approvals, improving collaboration as well as designing out inefficiencies. The other use is the ability to extract schedules which are then used for procurement to enable installation during construction.

There is a need for organizations to continue to review what BIM can do for them and how it can improve the way they work as its use increases and organizations continue to invest and develop led by BIM4Water. BIM definition has been explained, with BIM4Water preferring the term "Better Information Management" to make it express a better way of working which is leading to benefits being achieved in the water sector. Organizations should utilize BIM as a tool to create a competitive advantage as it is seen as being cost effective, which reduces project durations and improves quality of the end product. The open BIM platform and use of IFC for the sharing of digital information in different format should be taken advantage of and organizations like NBS and CITB should become more visible to the water industry.

Implications of this study are in two folds to the field of digitalisation of water industry and project delivery process. Firstly, the study provides a richer insight into the understanding and awareness of BIM elements use in the water industry to improve project delivery processes. Secondly, this paper demonstrates the use of BIM model for team discussions, seeking approvals, design reviews and the schedules for water project procurement. The study, therefore, bridges the theoretical and technical gaps and contributes to knowledge, by providing BIM elements currently used in the water industry, as well as understanding the organizational cultural support required for BIM implementation in the water industry project delivery processes. Furthermore, this study shows that the water industry supply chain has taken positive steps and started to benefit from BIM use. It is recommended that there is a need for cross-sector collaboration to capture and share best and worst practices relating to BIM adoption in the water sector. It is also recommended that the water companies continue to align itself with the construction industry best practice, embracing technology and using new tools. There should be an investment increase in the use of these tools as they so far proved effective in other areas of capital project delivery. This will enable the water industry to address the issues and challenges that it continues to face. This research recommends that further studies are carried out to determine the effects of mandating BIM for water projects as the UK government has done for public projects. 


\section{References}

Akintoye, A., and Renukappa, S., (2013), The UK Water Industry Infrastructure Governance and Procurement, in the book titled Water Governance: An Evaluation of Alternative Architectures, Edited by Asanga Gunawansa and Lovleen Bhullar, Edward Elgar Publishing, U.K.

Anglian Water (2014). Anglian Water names partners for $£ 450$ million AMP6 frameworks. Retrieved from http://www.anglianwater.co.uk/news/anglian-water-names-partners-for-450million-amp6-frameworks.aspx

Aranda-Mena, G., Crawford, J., Chevez, A. and Froese, T. (2009). Building information modelling demystified: does it make business sense to adopt BIM? International Journal of Managing Projects in Business, 2(3), 419-34

Autodesk (2015a) BIM for Infrastructure: The Impact of Today's Technology on BIM. Retrieved from http://static-dc.autodesk.net/content/dam/autodesk/www/campaigns/eni-owayour-bim/eni-owa-your-bim-4/technology-whitepaper-04.PDF

Autodesk (2015b,) BIM for Infrastructure: Is Civil Engineering Facing an Age of Extinction? Retrieved from http://static-dc.autodesk.net/content/dam/autodesk/www/campaigns/eni-owayour-bim/eni-own-bim-2/set2_whitepaper_cost_of_not_using_BIM_uk_new.pdf

Azhar, S., Hein, M. and Sketo, B. (2008). Building Information Modeling (BIM): Benefits, Risks and Challenges. McWhorter School of Building Science, Auburn University, USA

Bailey, P. (2003, February) The Business and Financial Structure of the Water Industry in England and Wales. Retrieved from

http://www.bath.ac.uk/management/cri/pubpdf/Research_Reports/14_Bailey.pdf

Beinstein P. G. and Pittman, J. H., (2004) Barriers to the Adoption of Building Information Modelling in the Building Industry. California. Autodesk Building Solutions

Bensalah, M., Elouadi, A. and Mharzi, H. (2019) Overview: the opportunity of BIM in railway, Smart and Sustainable Built Environment, 8(2), 103-116.

Beven, J., (2019) What future for water? Three challenges for the industry, https://www.gov.uk/government/speeches/what-future-for-water-three-challenges-for-the-industry

BIM4Water (2015) BIM Frequently Asked Questions Retrieved from http://www.bimtaskgroup.org/wp-content/uploads/2013/05/BIM4Water-FAQ.pdf

BIM4Water (2017) BIM Guidance for the Water Industry. Retrieved from https://www.britishwater.co.uk/media/Download.aspx?MediaId=1217

BIM4Water (2019). BIM4Water Case Studies. Retrieved from https://www.britishwater.co.uk/bim4water-case-studies.aspx

Bu, S., Shen, G., Anumba, C., Wong, A. and Liang, X. (2015), Literature review of green retrofit design for commercial buildings with BIM implication, Smart and Sustainable Built Environment, 4(2), 188-214. 
Building (2014). CPD 14 2014: BIM - collaboration and the common data environment Retrieved from http://www.building.co.uk/professional/cpd/cpd-14-2014-bim-collaborationand-the-common-data-environment/5068904.article

Cabinet Office (2011). Government Construction Strategy. Retrieved from www.gov.uk/government/uploads/system/uploads/attachment_data/file/61152/GovernmentConstruction-Strategy_0.pdf.

Chartered Institute of Building (CIOB), (2010). Code of Practice for Project Management for Construction and Development (4th Ed.) Oxford. Blackwell

Chartered Institute of Water and Environment Management (CIWEM), (2010). Regulation for a sustainable water industry. Retrieved from https://www.ciwem.org/assets/pdf/Policy/Reports/RSWI-FINAL.pdf

Construction Project Information Committee (2015) Making "Building Information Modelling" happen, CPIC publications, London.

Construction Enquirer (2015) AMP6. Retrieved from http://www.constructionenquirer.com/tag/amp6/

Corbin, J. and Strauss A. (2008) Basics of qualitative research. 3th ed. London: Sage.

Council for Science and Technology (CST), (2009). Improving innovation in the water industry: 21st century challenges and opportunities. Retrieved from http://www.ukwir.org/site/web/news/improving-innovation?xpm64409=65123

Creswell, J. W and Creswell, J. D., (2018) Research design: qualitative, quantitative, and mixed method Approaches, Los Angeles: Sage.

DEFRA (2019) Improving our management of water in the environment Consultation proposals, https://consult.defra.gov.uk/water/improving-management-of-water-in-theenvironment/supporting_documents/floodwaterconsultation190114.pdf

Denzin, N.K. and Lincoln, Y.S. (1998) (ed) Strategies of qualitative enquiry. London: Sage. Egan, J. (1998) Rethinking construction, Construction Task Force. London. HMSO Farrell, P (2011) Writing a Built Environment Dissertation: Practical guidance and examples. Oxford: Wiley-Blackwell.

Francis, J. J., Johnston, M., Robertson, C., Glidewell, L., Entwistle, V., Eccles, M. P. and Grimshaw, J. M. (2010) What is an adequate sample size? Operationalising data saturation for theory-based interview studies, Psychology \& Health, 25 (10), 1229 - 1245.

Galliford Try, Costain and Atkins (GCA) (2015) BIM in Action: How to Succeed with BIM podcast Retrieved from http://www.autodesk.co.uk/campaigns/eni-own-bim-5/thank-you

Hackett, R. (2018). Water companies plan $£ 50 B N$ on service improvements in AMP7. Retrieved from https://wwtonline.co.uk/news/water-companies-plan-50bn-on-serviceimprovements-in-amp7 
Hainworth, G. and Salvi, G. (2017) GB Water Industry for Dummies (2nd Ed). Chichester. John Wiley \& Sons Ltd

Hardin, B., and McCool., D, (2015). BIM and Construction Management: Proven Tools, Methods and Workflows. Indiana, John Wiley

Hart, C. (2005) Doing Your Masters Dissertation. London: Sage.

Holt, G. D. (1998). A guide to successful dissertation study for students of built environment. (2nd Ed.) Wolverhampton: University of Wolverhampton

Howell, S., Rezgui, Y., and Beach, T., (2017) Integrating building and urban semantics to empower smart water solutions, Automation in Construction, 81, 434-448.

HM Treasury and Cabinet Office (2016) Investing in Britain's future, https://assets.publishing.service.gov.uk/government/uploads/system/uploads/attachment_data/file/209 279/PU1524_IUK_new_template.pdf

HM Government. (2012) Industrial Strategy: government and industrial partnership. Building Information Modelling. London. HM Government

HM Government. (2013) Industrial Strategy: government and industrial partnership. Construction 2025. London. HM Government

Institution of Civil Engineers (ICE), (2015) Complete the annual BIM Heat Map survey and win a place at the ICE BIM Conference. Retrieved from https://www.ice.org.uk/news/complete-the-bim-heat-map-and-win-a-place Institution of Civil Engineers (ICE) (2017) From Transactions to Enterprises. A new approach to delivering high performing infrastructure. London. Infrastructure Client Group, ICE.

Kemp, A. (2014) The BIM phenomenon in the infrastructure Industry. Birmingham: ICE Khosrowshahi, F. and Arayici,Y., (2012). Roadmap for implementation of BIM in the UK construction industry. Engineering, Construction and Architectural Management, 19(6), 610 $-635$

Latham, M. (1994) Constructing the team, Final report of the government/industry review of procurement and contractual arrangements in the United Kingdom construction industry. London. HMSO, Department of Environment.

Liu, Z., Zhang, C., Guo, Y., Osmani, M., and Demian, P., (2019) A Building Information Modelling (BIM) based Water Efficiency (BWe) Framework for Sustainable Building Design and Construction Management, Electronics, pp. 1-19.

McKibbin, D. (2014) An examination of business models within the Water and Sewerage Industry in the UK and Republic of Ireland, Northern Ireland Assembly - Reasearch and Informative Service Research Paper, Sep, Available:

http://www.niassembly.gov.uk/globalassets/Documents/RaISe/Publications/2014/Regional/10514.pdf. Moshtaghian, F., Golabchi, M., and Noorzai, E., (2020) A framework to dynamic 
identification of project risks, Smart and Sustainable Built Environment. https://doi.org/10.1108/SASBE-09-2019-0123.

Naoum, S. (2007). Dissertation Research \& Writing for Construction Students. Oxford. Butterworth-Heinemann.

NBS (2017), (2017) What is IFC. Retrieved from https://www.thenbs.com/knowledge/whatis-ifc

NBS (2019) National BIM Report 2019, London: RIBA Enterprises Ltd.

Neuman, W. (2014) Social Research Methods - Qualitative and Quantitative Approaches (7th ed.) London: Pearson Education Inc

New Civil Engineer (NCE), (2014) Infrastructure in 2014: Why harvesting data is the new BIM. Retrieved from https://www.newcivilengineer.com/infrastructure-in-2014-whyharvesting-data-is-the-new-bim/8656981.article

Ofwat (2019) UK Government priorities and our 2019 price review final determinations, https://www.ofwat.gov.uk/wp-content/uploads/2019/12/UK-Government-priorities-and-our2019-price-review-final-determinations.pdf

Potton, E., and Adcock, A., (2019) Future of the water industry in England and Wales, https://researchbriefings.parliament.uk/ResearchBriefing/Summary/CDP-20190008\#fullreport

Rahimian, F., Seyedzadeh, S., Oliver, S., Rodriguez, S. \& Dawood, N., (2020) On-Demand Monitoring of Construction Projects through a Game-Like Hybrid Application of BIM and Machine Learning, Automation in Construction, 110, 14 p., 103012.

Rezgui, Y., Zarli, A. and Hopfe, C.J. (2009) Editorial - Building Information Modelling Applications, Challenges and Future Directions. Journal of Information Technology in Construction, 14(7), 613-616

Rezgui, Y. and Zarli, A (2006). Paving the way to digital construction: a strategic roadmap. Journal of Construction Management and Engineering, 132(7), 767-776

Robson, C. (2011) Real World Research, West Sussex, UK: John Wiley and Sons Ltd Royal Institute of British Architects (RIBA) (2012) BIM Overlay to the RIBA Outline Plan of Work. London: RIBA

Saieg, P., Dominguez Sotelino, E., Nascimento, D., Goyannes Gusmao Caiado., R., (2018) Interactions of Building Information Modeling, Lean and Sustainability on the Architectural, Engineering and Construction industry: A systematic review, Journal of Cleaner Production, 174, 788-806.

Smith, C., (2016) How BIM is Redefining Water, Water World, https://www.waterworld.com/drinking-water/distribution/article/16202014/how-bim-isredefining-water.

Schwandt, T.A (2009) Dictionary of Qualitative enquiry, London: Sage. 
Tajeddini, K. and S. Mueller (2009) Entrepreneurial characteristics in Switzerland and the UK: A comparative study of techno-entrepreneurs, Journal of International

Entrepreneurship, 7, 1-25.

The National Audit Office (NAO, 2015) The economic regulation of the water sector, https://www.nao.org.uk/wp-content/uploads/2014/07/The-economic-regulation-of-the-watersector.pdf

Thames Water (2013) Alliance formed for 2015 to 2020 investment programme. Retrieved from www.thameswater.co.uk/media/press-releases/17101.htm

The Water Services Regulatory Authority (Ofwat), (2015) Water Companies Today.

Retrieved from https://www.ofwat.gov.uk/industryoverview/today/watercompanies\#wasc

The Water Services Regulatory Authority (Ofwat) and Department for Environment, Food \& Rural Affairs (Defra), (2006) The development of the Water Industry in England and Wales: Ofwat Retrieved from www.ofwat.gov.uk/publications/.../rpt_com_devwatindust270106.pdf

Water Industry Forum (WIF) (2015) BIM - reducing costs in the water sector. Retrieved from http://www.waterindustryforum.com/member-services/events/wif-events/bim-reducingcosts-in-the-water-sector/

Wei, T., Chen, G. and Wang, J., (2017) Application of BIM Technology in Building Water Supply and Drainage Design, IOP Conference Series Earth and Environmental Science, pp. $1-5$. 
Table 1: UK WOCs and WaSCs (Hainworth and Salvi, 2017)

\begin{tabular}{|c|c|c|c|}
\hline Water and Sewerage Companies & $\begin{array}{l}\text { Customer } \\
\text { (millions) }\end{array}$ & Water Only Companies & $\begin{array}{l}\text { Customer } \\
\text { (millions) }\end{array}$ \\
\hline Anglian & 6.7 & Affinity & 3.5 \\
\hline Dwr Cymru (Welsh Water) & 4.1 & Bristol & 1.1 \\
\hline Northern Ireland & 1.8 & Dee Valley & 0.3 \\
\hline Northumbrian (inc Essex \& suffolk) & 3.6 & Portsmouth & 0.7 \\
\hline Scottish & 6.7 & Bournemouth & 0.5 \\
\hline Severn Trent & 10.4 & South East & 2.1 \\
\hline South West & 1.6 & Sutton \& East Surrey & 0.7 \\
\hline Southern & 4.6 & \multirow{5}{*}{$\begin{array}{l}\text { South Staffordshire (including } \\
\text { Cambridge) }\end{array}$} & \multirow{5}{*}{1.6} \\
\hline Thames & 14.9 & & \\
\hline United Utilities & 8.5 & & \\
\hline Wessex & 3.1 & & \\
\hline Yorkshire & 6.0 & & \\
\hline
\end{tabular}

Table 2: Observation protocol

\begin{tabular}{|c|c|}
\hline Descriptive Notes & Reflective Notes \\
\hline $\begin{array}{l}\text { Data exchange between client and designer - } \\
\text { Initial project start up meeting and collation of } \\
\text { Pre-Construction Information }\end{array}$ & $\begin{array}{l}\text { Client provides designer with 2D drawings from } \\
\text { previous projects and documents. Extensive work } \\
\text { is identified as required to build 3D models or use } \\
\text { BIM. }\end{array}$ \\
\hline $\begin{array}{l}\text { Data exchange between designer and suppliers / } \\
\text { sub-contractors - Designer sends out works } \\
\text { tenders to various suppliers and sub-contractors }\end{array}$ & $\begin{array}{l}\text { Designer initially sent a tender request requesting } \\
\text { costs and associated drawings and respective costs } \\
\text { on tender return. On placing of order designer } \\
\text { requests 3D models in CAD and in BIM format. } \\
\text { Supplier only sends 3D AutoCAD drawings. } \\
\text { Supplier has no capability to prepare data in } \\
\text { requested format }\end{array}$ \\
\hline $\begin{array}{l}\text { Data exchange between designer and technician - } \\
\text { Designer sends available data to technician }\end{array}$ & $\begin{array}{l}\text { Information from supplier / sub-contractor is sent } \\
\text { to technician through a common data environment }\end{array}$ \\
\hline
\end{tabular}

Table 3: Organizations' profiles and a breakdown of professionals who were interviewed for the study

\begin{tabular}{|c|c|c|c|c|c|c|}
\hline $\begin{array}{l}\text { Organizatio } \\
\text { n }\end{array}$ & $\begin{array}{l}\text { Size (no. of employees \& } \\
\text { approx. turnover in } £ \text { ) }\end{array}$ & $\begin{array}{l}\text { Organizations' } \\
\text { Operation } \\
\text { Nature }\end{array}$ & $\begin{array}{l}\text { Operation } \\
\text { Scope }\end{array}$ & $\begin{array}{l}\text { BIM } \\
\text { elements use } \\
\& \\
\text { application } \\
\text { extent }\end{array}$ & $\begin{array}{l}\text { Responsibility of } \\
\text { interviewee in the } \\
\text { organization }\end{array}$ & $\begin{array}{l}\text { No. of } \\
\text { Interviews }\end{array}$ \\
\hline A & $\begin{array}{l}\text { - } \quad 16,000 \text { employees } \\
\text { - } \quad £ 1,401 \text { million }\end{array}$ & $\begin{array}{l}\text { Engineering } \\
\text { consultancy }\end{array}$ & International & $\begin{array}{l}\text { Medium } \\
\text { High }\end{array}$ & $\begin{array}{ll}\text { - } & \text { Project Leader } \\
\text { - } & \text { BIM Team Leader } \\
\text { - } & \text { BIM Technicians }\end{array}$ & $\begin{array}{l}1 \\
1 \\
3\end{array}$ \\
\hline B & $\begin{array}{ll}\text { - } & \text { 2,000 employees } \\
\text { - } & £ 0,8 \text { billion } \\
\end{array}$ & $\begin{array}{l}\text { Utilities } \\
\text { company }\end{array}$ & Regional & Low & $\begin{array}{l}\text { - } \begin{array}{l}\text { Programme Engineer / } \\
\text { Manager }\end{array} \\
\end{array}$ & 1 \\
\hline $\mathrm{C}$ & $\begin{array}{ll}\text { - } & 3,000 \text { employees } \\
\text { - } & £ 779 \text { million }\end{array}$ & $\begin{array}{l}\text { Utilities } \\
\text { company }\end{array}$ & Regional & Low & $\begin{array}{l}\text { - Asset Manager / } \\
\text { Operator }\end{array}$ & 1 \\
\hline $\mathrm{D}$ & $\begin{array}{l}\text { - } \quad 13,000 \text { employees } \\
\text { - } \quad £ 1.5 \text { billion }\end{array}$ & $\begin{array}{l}\text { Engineering } \\
\text { Consultancy }\end{array}$ & International & $\begin{array}{l}\text { Medium } \\
\text { High }\end{array}$ & $\begin{array}{ll}\text { - } & \text { Project Managers } \\
\text { - } & \text { CAD Technicians }\end{array}$ & $\begin{array}{l}3 \\
2\end{array}$ \\
\hline $\mathrm{E}$ & $\begin{array}{ll}\text { - } & 14,000 \text { employees } \\
\text { - } & £ 1.5 \text { billion }\end{array}$ & $\begin{array}{l}\text { Engineering } \\
\text { Consultancy }\end{array}$ & International & Medium & - $\quad$ Technical Manager & 1 \\
\hline $\mathrm{F}$ & $\begin{array}{ll}\text { - } & 6,000 \text { employees } \\
\text { - } & £ 1,694 \text { billion }\end{array}$ & $\begin{array}{l}\text { Utilities } \\
\text { company }\end{array}$ & Regional & Low & - $\quad$ Design Lead & 1 \\
\hline
\end{tabular}


Table 4: BIM measures in use

\begin{tabular}{|c|c|c|c|}
\hline BIM measures in use & Purpose & $\begin{array}{l}\text { Organisation } \\
\text { implementing } \\
\text { measures }\end{array}$ & Sample comment on BIM elements implementation \\
\hline $\begin{array}{l}\text { Use of information } \\
\text { management collaborative } \\
\text { cloud based platform }\end{array}$ & Collaborative working & A, B, C, D, E \& F & $\begin{array}{l}\text { "In my organisation a view was taken that we should have } \\
\text { a central source for the data that would be used by our } \\
\text { various departments around the world" (Project Leader). }\end{array}$ \\
\hline $\begin{array}{l}\text { Use of BIM information } \\
\text { modelling technology } \\
\text { (Autodesk suite) }\end{array}$ & $\begin{array}{l}\text { BIM and its elements } \\
\text { adoption }\end{array}$ & A, D, \& E & $\begin{array}{l}\text { "I have done some work in BIM but I know this will be a } \\
\text { growing part of my daily work" (CAD Technician). }\end{array}$ \\
\hline $\begin{array}{l}\text { Creation and adoption of } \\
\text { BIM execution plans }\end{array}$ & $\begin{array}{l}\text { BIM and its elements } \\
\text { adoption }\end{array}$ & $\mathrm{A}, \mathrm{D}, \& \mathrm{E}$ & $\begin{array}{l}\text { "A draft BIM execution plan” has been in circulation for a } \\
\text { while on this framework contract. It is only now that more } \\
\text { emphasis is being placed on issuing a working version". } \\
\text { (Project Manager) }\end{array}$ \\
\hline $\begin{array}{l}\text { Training of staff in BIM } \\
\text { implementation in project } \\
\text { delivery }\end{array}$ & $\begin{array}{l}\text { BIM and its elements } \\
\text { adoption }\end{array}$ & $\mathrm{A}, \mathrm{D}, \& \mathrm{E}$ & $\begin{array}{l}\text { I see on the job training and having a mentor as key to } \\
\text { successful BIM implementation (CAD Technician). }\end{array}$ \\
\hline
\end{tabular}

Table 5: In house measures

\begin{tabular}{|c|c|c|}
\hline In house measures & $\begin{array}{l}\text { Organisation } \\
\text { implementing } \\
\text { measures }\end{array}$ & Sample comment on in house measures \\
\hline $\begin{array}{l}\text { Extracting schedules \& documents } \\
\text { from BIM models for procurement \& } \\
\text { construction }\end{array}$ & A \& E & $\begin{array}{l}\text { "One of the not spoken about benefit is the ease of extracting schedules at } \\
\text { the click of a button instead of manual entry. Once the design has been } \\
\text { completed, checked and accepted, schedules are extracted, of the right } \\
\text { components, first time and sent to the QS for procurement" (Project } \\
\text { Leader). }\end{array}$ \\
\hline $\begin{array}{l}\text { Extracting three dimensional visuals } \\
\text { for project discussions and approvals }\end{array}$ & $\mathrm{A}, \mathrm{D}, \mathrm{\&} \mathrm{E}$ & $\begin{array}{l}\text { "It is often easier for lots of people to see a } 3 \mathrm{D} \text { model than to understand } \\
2 \mathrm{D} \text { drawings. I have anecdotal evidence that we have also provided } \\
\text { walkthroughs of intended design so operatives are able to comment on } \\
\text { how our design will either assist or hinder them in what they do" (CAD } \\
\text { Technician). }\end{array}$ \\
\hline $\begin{array}{l}\text { Participation in industry water } \\
\text { industry “BIM4Water” BIM working } \\
\text { group }\end{array}$ & A, B, C, D, E \& F & $\begin{array}{l}\text { “I am aware of our organisation's participation within this forum even } \\
\text { though there isn't much publicity about it. I follow the forums they hold } \\
\text { to keep up to date with where the water industry is heading so that I can } \\
\text { discuss with my managers on how our work fits in”. (Technical Manager) }\end{array}$ \\
\hline $\begin{array}{l}\text { Adoption of BIM as standard for } \\
\text { project execution }\end{array}$ & A & $\begin{array}{l}\text { "My organisation has been a fore runner in BIM for years and I believe } \\
\text { are pushing the boundaries of what we can achieve in BIM at present" } \\
\text { (Project Leader). }\end{array}$ \\
\hline
\end{tabular}


Table 6: Organisations’ BIM interests and next steps

\begin{tabular}{|c|c|c|c|}
\hline & Client, water company & Engineering consultant & Supply chain \\
\hline BIM Interests & $\begin{array}{ll}- & \text { 3D views for asset, what am I } \\
\text { buying? } \\
\text { - } & \text { What does it look like? } \\
\text { - } & \text { What does it do and how do I use } \\
\text { - } & \text { How does it make me meet } \\
\text { - } & \text { regulations? } \\
\text { - } & \text { Cow do I maintain it? } \\
\end{array}$ & $\begin{array}{ll}\text { - } & \text { Ability and capability to } \\
\text { develop models efficiently } \\
\text { - } & \text { Collaborative working } \\
\text { - } & \text { Hardware and software } \\
\text { resources } \\
\text { - } \quad \text { Trained, experienced CAD } \\
\text { technicians and engineers }\end{array}$ & $\begin{array}{l}\text { - } \quad \text { What elements, equipment do } \\
\text { - } \quad \text { Hou need? } \\
\text { - } \quad \text { Descriptions? } \\
\text { - } \quad \text { Collaborative working } \\
\text { - } \quad \text { Details etc. }\end{array}$ \\
\hline $\begin{array}{l}\text { Current and } \\
\text { future needs }\end{array}$ & $\begin{array}{l}\text { - Currently no need to know how to } \\
\text { develop the BIM model } \\
\text { - Will BIM be a mandate in private } \\
\text { sector? }\end{array}$ & \multicolumn{2}{|c|}{$\begin{array}{l}\text { Gain / maintain competitive advantage } \\
\text { Cost and cost savings } \\
\text { Keep up with industry advancement } \\
\text { Meet industry requirements (currently mandated in public projects, } \\
\text { maybe for large capital projects, e.g. any scheme with a capital } \\
\text { scheme over } £ 10 \text { million) }\end{array}$} \\
\hline
\end{tabular}



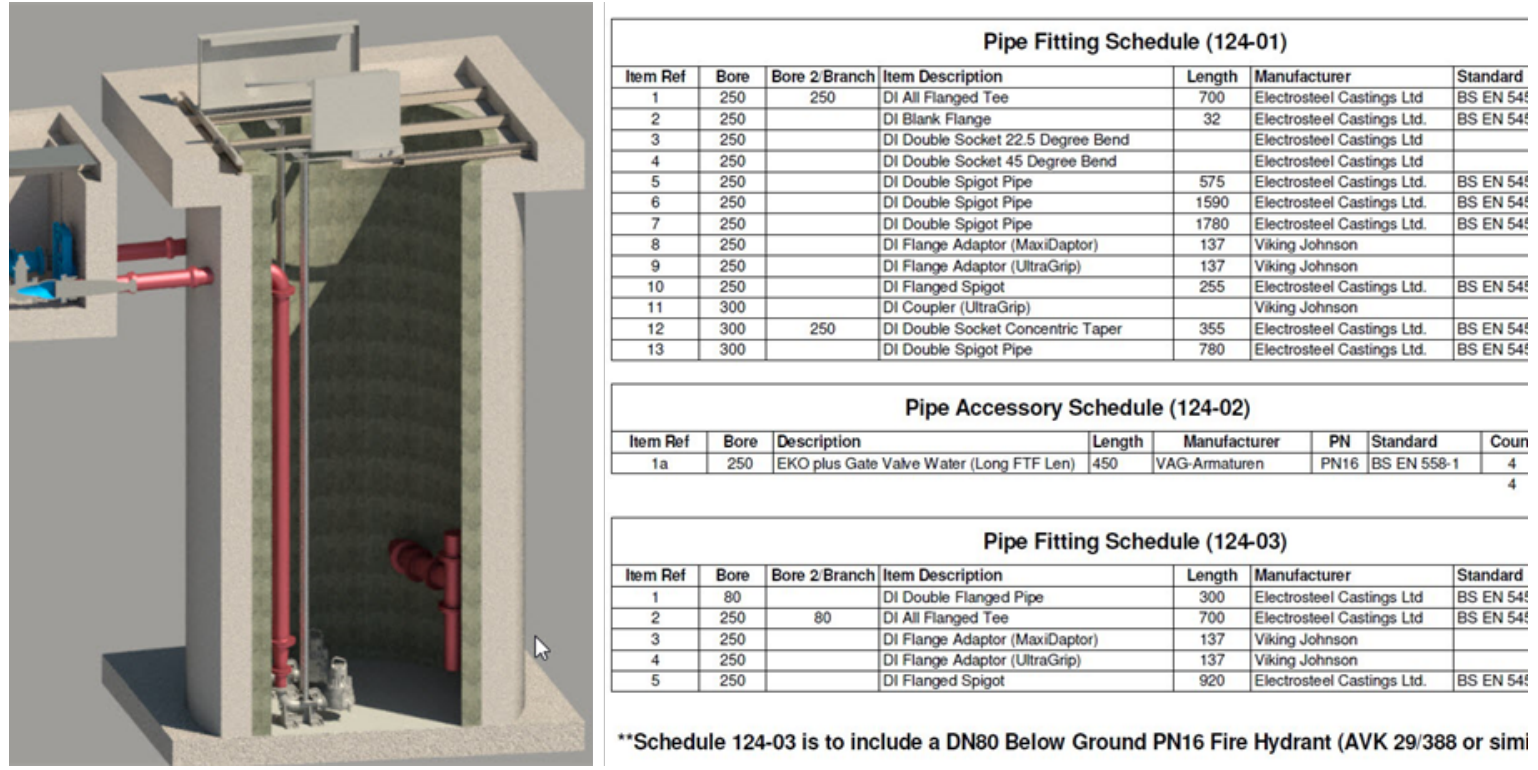

Pipe Accessory Schedule (124-02)

Pipe Accessory Schedule (124-02)
\begin{tabular}{|c|c|c|c|c|c|c|c|}
\hline Item Ref & Bore & Description & Length & Manufacturer & PN & Standard & Coun \\
\hline 1a & 250 & EKO plus Gate Vave Water (Long FTF Len) & 450 & VAG-Armaturen & PN16 & BS EN 558-1 & 4 \\
\hline
\end{tabular}

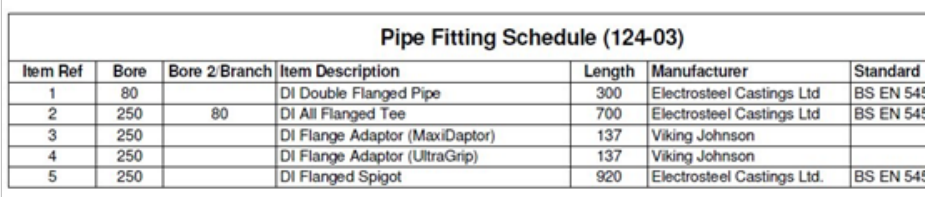

"Schedule 124-03 is to include a DN80 Below Ground PN16 Fire Hydrant (AVK 29/388 or simi

Figure 1: BIM software model visuals and outputs of a sewage pumping station (Source: organisations A \& D) 